Shareholder Activism 
This page intentionally left blank 


\title{
Shareholder Activism
}

\section{Corporate Governance Reforms in Korea}

\author{
Han-Kyun Rho
}

BRESE Research Lecturer

Brunel Business School

Brunel University, UK

Foreword by

Robert A.G. Monks 


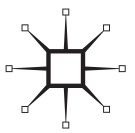

(c) Han-Kyun Rho 2007

Softcover reprint of the hardcover 1st edition 2007 978-1-4039-9160-7

All rights reserved. No reproduction, copy or transmission of this publication may be made without written permission.

No paragraph of this publication may be reproduced, copied or transmitted save with written permission or in accordance with the provisions of the Copyright, Designs and Patents Act 1988, or under the terms of any licence permitting limited copying issued by the Copyright Licensing Agency, 90 Tottenham Court Road, London W1T 4LP.

Any person who does any unauthorised act in relation to this publication may be liable to criminal prosecution and civil claims for damages.

The author has asserted his right to be identified as the author of this work in accordance with the Copyright, Designs and Patents Act 1988.

First published 2007 by

PALGRAVE MACMILLAN

Houndmills, Basingstoke, Hampshire RG21 6XS and

175 Fifth Avenue, New York, N.Y. 10010

Companies and representatives throughout the world

PALGRAVE MACMILLAN is the global academic imprint of the Palgrave Macmillan division of St. Martin's Press, LLC and of Palgrave Macmillan Ltd. Macmillan ${ }^{\oplus}$ is a registered trademark in the United States, United Kingdom and other countries.

Palgrave is a registered trademark in the European Union and other countries.

ISBN 978-1-349-54298-7

DOI 10.1057/9780230625822

ISBN 978-0-230-62582-2 (eBook)

This book is printed on paper suitable for recycling and made from fully managed and sustained forest sources.

A catalogue record for this book is available from the British Library.

Library of Congress Cataloging-in-Publication Data

Rho, Han-Kyun, 1965-

Shareholder activism : corporate governance reforms in Korea /

Han-Kyun Rho.

p. $\mathrm{cm}$.

Includes bibliographical references and index. I. Title.

1. Corporate governance-Korea (South) 2. Stockholders-Korea (South)

HD2741.R48 2007

$338.6095195-\mathrm{dc} 22$

2006049097

$\begin{array}{rrrrrrrrrr}10 & 9 & 8 & 7 & 6 & 5 & 4 & 3 & 2 & 1\end{array}$

$\begin{array}{llllllllll}16 & 15 & 14 & 13 & 12 & 11 & 10 & 09 & 08 & 07\end{array}$ 
To my family and friends 
This page intentionally left blank 


\section{Contents}

List of Tables ix

List of Figures $\quad \mathrm{x}$

Acknowledgements - xi

List of Abbreviations $\quad$ xii

Note on Korean Spelling xiv

Foreword by Robert A.G. Monks $\quad$ XV

Introduction: Shareholder Activism and Corporate

Governance Reform

Part I A Review of Theories 1

1 Defining the Object of Study 3

Previous definitions of shareholder activism 4

Three dimensions of shareholder activism $\quad 5$

$\begin{array}{ll}\text { Meaning of emergence } & 14\end{array}$

2 Explaining Activism (1): Existence of a Problem 17

$\begin{array}{ll}\text { Theoretical backgrounds } & 17\end{array}$

$\begin{array}{ll}\text { Investigation methods } & 18\end{array}$

Research results $\quad 22$

$\begin{array}{ll}\text { Further thoughts } & 24\end{array}$

3 Explaining Activism (2): Determinants of Choice 26

$\begin{array}{ll}\text { Theoretical backgrounds } & 26\end{array}$

Determinants of activism choice 28

$\begin{array}{ll}\text { Investigation results } & 31\end{array}$

$\begin{array}{ll}\text { Further thoughts } & 34\end{array}$

4 Explaining Activism (3): Politics and Interpretations 36

Theoretical backgrounds: social movement theory $\quad 36$

Investigation results $\quad 41$ 
Part II An Application: the Korean PSPD Case 45

5 Political Opportunity $\quad 47$

Formal opportunity: government policy 47

Informal opportunity: power relations $\quad 58$

$\begin{array}{lll}6 & \text { Framing Process } & 67\end{array}$

Three frames from the past $\quad 67$

Approaching shareholder rights $\quad 69$

Korea First Bank: the first attempt $\quad 72$

$\begin{array}{ll}\text { From a trial to regular use } & 75\end{array}$

$\begin{array}{ll}\text { Frame alignment and a minimalist strategy } & 80\end{array}$

Limitations of the PSPD activism $\quad 83$

7 Resource Mobilization $\quad 86$

Internal resources $\quad 86$

External resources $\quad 95$

8 Conclusion 119

Findings on three emergences 119

$\begin{array}{ll}\text { Implications } & 126\end{array}$

$\begin{array}{ll}\text { Notes } & 134\end{array}$

$\begin{array}{ll}\text { References } & 141\end{array}$

$\begin{array}{ll}\text { Index } & 155\end{array}$ 


\section{List of Tables}

1.1 Three dimensions of previous definitions 5

2.1 Results from single variable comparisons 23

2.2 Results from probability regressions 24

3.1 Percentages of the indexed equity portfolio, US 32

$\begin{array}{lll}4.1 & \text { Two types of political opportunities } & 39\end{array}$

5.1 Shareholding requirements for minority shareholder rights

5.2 Internal ownership of the 30 biggest chaebol, 1983-1999

$\begin{array}{lll}5.3 & \text { CCEJ activities related to the chaebol, 1990-1996 } & 60 \\ 5.4 & \text { PSPD shareholder activism, 1997-1999 }\end{array}$

6.1 Reframing the chaebol problem 82

7.1 Composition of the PEC executive members, 1997-2000

7.2 Income of the PEC (won), 1998-2000 94

7.3 Shareholder supports for the PEC's legal actions 98

7.4 PSPD shareholding of the chaebol, as of 28 February 2001

$\begin{array}{lll}7.5 & \text { Shareholder composition of the PSPD targets } & 101\end{array}$

7.6 Participants in the 10-Share Campaign, as of 8 Feb. 2000

7.7 Domestic institutional shareholdings, as of 31 Dec. $2000 \quad 105$

7.8 Institutional shareholdings (\%), 1986-1999 106

7.9 Institutions controlled by non-financial companies, as of 31 July 1999

7.10 Institutional investors' voting in the AGMs of all listed firms

7.11 Positions of institutional investors 108

7.12 Institutions' response to a PSPD proposal in Samsung Electronics

7.13 Comparing shareholder groups 118

8.1 Two models of corporate governance 130 


\section{List of Figures}

0.1 Shareholder activism in corporate governance reform xviii

0.2 Growth of shareholder resolutions, US, 1987-2005 xix

1.1 Monitoring and shareholder activism 11

1.2 Interactive model of shareholder activism 13

1.3 Number of resolutions per activists, US, 1995-2005 15

1.4 Three outstanding activists, US, 1995-2005 16

2.1 CAR for target companies 20

2.2 Inference in the first approach 20

5.1 Internal ownership of the 30 biggest chaebol, 1983-1999 52

5.2 Succession to the chairmanship in the four biggest chaebol 53

6.1 Three past frames 69

6.2 Press releases and news reports, 1997-2000 77

6.3 New framing from the old frames 82

7.1 Composition of the PEC income 94

7.2 Institutional shareholdings (\%), 1986-1999 106

7.3 Growth of ESOAs, 1990-2000 111

8.1 Dynamics of collective action organization 125

8.2 Assumptions underlying corporate governance reforms 128

8.3 Shareholder activism as spinning cogwheels 129

8.4 Circular relation between the two models 131 


\section{Acknowledgements}

My study at Cambridge University, the starting point of this long journey, would not have been possible without support from both the UK and Korean governments. The Foreign Commonwealth Office generously offered me the Chevening Scholarship and the Ministry of Commerce, Industry and Energy, my former employer, provided me with financial support including two years' paid leave. The research was also funded in part by the R.A.G. Monks Scholarship and Cambridge Political Economy Society Trust, for which I am very grateful.

This book is a result of the valuable time and experiences that the interviewees allowed me. Especially, I would like to thank the members of the People's Solidarity of Participatory Democracy (PSPD), including Hasung Jang and Seung-Hee Lee. In addition, Sang-Jo Kim, currently Chairman of the Participatory Economy Committee and Director of Chaebol Reform Monitoring Centre of the PSPD, reviewed the early drafts to give the book a lively and balanced description.

I am also indebted to the Korea Development Institute (KDI) that provided me an excellent research environment during the fieldwork in Seoul, Korea. I would like to express special gratitude to Seong Min Yoo for arranging my affiliation to the KDI. Kyong-koo Han, an anthropology professor now at Kookmin University, Korea, was a really comforting beacon to a novice fieldworker. I would like to thank John Hendry, Ha-Joon Chang, Ronald Dore and Peter Nolan whose incisive comments and constructive criticism have been an invaluable source of stimulation and encouragement.

I am grateful to the Von Hügel Institute, the European Business Ethics Network-UK, and European Group for Organizational Studies for having offered me an opportunity to share my research idea with colleagues. Alice Lam, my old colleague at Brunel and now at Royal Holloway, University of London, thankfully encouraged me to write this book. I would also like to thank Jacky Kippenberger of Palgrave Macmillan and Katie Jones of Judge Business School, Cambridge, for their help in the production of this book.

Finally, the research life made me understand why most scholars make acknowledgement of their families' patience. Like other fellow researchers, I also owe immeasurable thanks to my family - Hye-Sun, JongYoun, Curie, my parents, and my mother-in-law, to name a few nearest for the loving support which they provided to me during my research.

Han-Kyun

Cambridge, UK 


\section{List of Abbreviations}

\begin{tabular}{|c|c|}
\hline ABI & Association of British Insurers \\
\hline ACGA & Asian Corporate Governance Association \\
\hline AFL-CIO & $\begin{array}{l}\text { American Federation of Labor and Congress of } \\
\text { Industrial Organizations }\end{array}$ \\
\hline AGM & annual general meeting \\
\hline APEC & Asia Pacific Economic Co-operation \\
\hline AR & average abnormal return \\
\hline ASA & Australian Shareholders Association \\
\hline ASrIA & $\begin{array}{l}\text { Association for Sustainable and Responsible } \\
\text { Investment in Asia }\end{array}$ \\
\hline BOK & Bank of Korea \\
\hline BW & bond with warrant \\
\hline CalPERS & California Public Employee Retirement System \\
\hline Calstrs & California State Teachers Retirement System \\
\hline CAR & cumulative average return \\
\hline CB & convertible bond \\
\hline CCEJ & Citizens' Coalition for Economic Justice (Korea) \\
\hline CGCG & Center for Good Corporate Governance (Korea) \\
\hline CII & Council of Institutional Investors (US) \\
\hline Colpera & Colorado Public Employee Retirement System \\
\hline CRSP & Center for Research in Security Prices \\
\hline DSW & $\begin{array}{l}\text { Deutsche Schutzvereinigung für Westpapierbesitz } \\
\text { (Germany) }\end{array}$ \\
\hline EGM & extraordinary general meeting \\
\hline EIU & Economist Intelligence Unit \\
\hline EPB & Economic Planning Board (Korea) \\
\hline Eurosif & $\begin{array}{l}\text { European Sustainable and Responsible Investment } \\
\text { Forum }\end{array}$ \\
\hline FIGHT & Freedom, Integration, God, Honor-Today (US) \\
\hline FSBA & Florida State Board of Administration \\
\hline FSC & Financial Supervisory Commission (Korea) \\
\hline EIRIS & $\begin{array}{l}\text { Ethical Investment Research and Information } \\
\text { Service (UK) }\end{array}$ \\
\hline ERISA & Employee Retirement Income Security Act (US) \\
\hline ESOA & employee stock ownership association (Korea) \\
\hline FKI & Federation of Korean Industries \\
\hline
\end{tabular}




$\begin{array}{ll}\text { FOE } & \text { Friends of the Earth } \\ \text { FSC } & \text { Financial Supervisory Commission (Korea) } \\ \text { FSS } & \text { Financial Supervisory Service (Korea) } \\ \text { FTC } & \text { Fair Trade Commission (Korea) } \\ \text { ICCR } & \text { Interfaith Center on Corporate Responsibility (US) } \\ \text { ICGN } & \text { International Corporate Governance Network } \\ \text { IFMA } & \text { Institutional Fund Mangers' Association (UK) } \\ \text { IMF } & \text { International Monetary Fund } \\ \text { IRAA } & \text { Investors Rights Association of America } \\ \text { IRRC } & \text { Investor Responsibility Research Center (US) } \\ \text { ISS } & \text { Institutional Shareholder Services (US) } \\ \text { KCCI } & \text { Korea Chamber of Commerce and Industry } \\ \text { KCTU } & \text { Korean Confederation of Trade Unions } \\ \text { KDI } & \text { Korea Development Institute } \\ \text { KFB } & \text { Korea First Bank } \\ \text { KIF } & \text { Korea Institute of Finance } \\ \text { KINDS } & \text { Korea Integrated News Database System } \\ \text { KLCA } & \text { Korea Listed Companies Association } \\ \text { KSE } & \text { Korea Stock Exchange } \\ \text { KSE-KIND } & \text { Korea Investor's Network for Disclosure System, KSE } \\ \text { LAPFF } & \text { Local Authority Pension Fund Forum (UK) } \\ \text { MOFE } & \text { Ministry of Finance and Economy (Korea) } \\ \text { MOTIE } & \text { Ministry of Trade, Industry and Energy (Korea) } \\ \text { NAPF } & \text { National Association of Pension Funds (UK) } \\ \text { NYSCR } & \text { New York State Common Retirement System } \\ \text { OECD } & \text { Organization for Economic Co-operation and } \\ & \text { Development } \\ \text { OSS } & \text { Office of Securities Supervision (Korea) } \\ \text { PEC } & \text { Participatory Economy Committee, PSPD } \\ \text { PIRC } & \text { Pensions \& Investment Research Consultants Ltd (UK) } \\ \text { PSPD } & \text { People's Solidarity for Participatory Democracy (Korea) } \\ \text { S\&P 500 } & \text { Standard \& Poor's 500 Common Stock Index } \\ \text { SEC } & \text { Securities and Exchange Commission (US) } \\ \text { SIC } & \text { Standard Industrial Classification } \\ \text { SMWIA } & \text { Sheet Metal Workers' International Association } \\ \text { SWIB } & \text { State of Wisconsin Investment Board } \\ \text { TIAA-CREF } & \text { Teachers Insurance and Annuity Association: College } \\ & \text { Retirement Equities Fund (US) } \\ \text { UBCJA } & \text { United Brotherhood of Carpenters and Joiners of America } \\ \text { UKSA } & \text { United Kingdom Shareholders Association } \\ \text { USA } & \text { United Shareholders Association (US) } \\ & \end{array}$




\section{Note on Korean Spelling}

It is not easy to convey Korean pronunciation, with precision, via the English alphabet. The McCune-Reischauer System (or the Martin System for linguists) is the converting system that Western authors have usually resorted to. Notwithstanding, this book is based on a new guideline How to Romanize Korean prepared by the Korean government (Ministry of Culture and Tourism, Public Notice No. 2000-8).

I have tried to spell proper nouns as preferred by the individuals concerned. When it is difficult to identify their spelling, I followed the aforementioned guideline. With Korean names, the surname traditionally comes first. The given name then follows in the form of one word (whether hyphenated or not) or two words. To avoid Westerners' confusion, many Koreans, including myself, invert their names. This book has kept to the Korean way in its main body. Elsewhere, including the cover and acknowledgements, the name is inverted. 


\section{Foreword}

There is a compelling neatness about the Korean iteration of shareholder activism. The syllogism is that national wealth is enhanced through corporate growth; the legitimate definition of wealth is political as well as economic; therefore, the process of monitoring corporate power is necessary - shareholder activists, thus, are performing a public good.

The asserted congruency of corporate and national interest colors shareholder involvement with purpose. It is a device through which the power of the chaebol can effectively be addressed without disturbing the delicate equilibrium of public and private power. "The virtuous cycle between corporate governance reform and shareholder activism" compels the conclusion that financial support for this institution should be forthcoming either from the corporation itself or from the government. Unhappily, the incapacity of societies to deal with the disabling conflicted interests of institutional investors - the largest global shareholders - deprives the movement of the breadth and depth of support necessary for full effectiveness.

The splendid tradition of courageous personal activism that has distinguished the last half century of Korean history is a unique and welcome addition to the global tapestry of corporate governance.

Robert A.G. Monks

Principal, Lens Governance Advisors

\& Chairman, Governance for Owners, LLP 
This page intentionally left blank 


\section{Introduction: Shareholder Activism and Corporate Governance Reform}

In recent years, there has been growing interest, both political and academic, in the operation and reform of international systems of corporate governance. ${ }^{1}$ Of particular interest, in the wake of the 1997 Asian crisis, have been the use of shareholder rights and the encouragement of shareholder activism ${ }^{2}$ in reforming corporate governance regimes (e.g., IMF staff, 1998).

Among policymakers, the general consensus has been that there exists a virtuous cycle between corporate governance reform and shareholder activism. With policy support, shareholders can monitor and thus assert their interest to corporate management more forcefully than before. This shareholders' self-assertion forces managers to adopt a more shareholderinterest-centered stance than before. Shareholder- or investor-centered management brings about more efficient operations, and thus the national economy as a whole can secure the foundation for sustainable growth. It is widely believed that the sustainable growth of the economy is one of the key policy goals a national government should achieve, and accordingly, corporate governance reform encouraging shareholder activism is regarded as desirable. Meanwhile, as a shareholder-centered view of firms becomes gradually more widespread, demands for the protection of shareholder interests will also increase, which will in turn reinforce shareholdercentered corporate governance reform.

The significance of shareholder activism within the overall process of corporate governance reform can be summarized as in Figure 0.1. For this reason, encouraging shareholder monitoring has been recommended as an important goal for corporate governance reform (e.g., Iskander, Meyerman, Gray and Hagan, 1999). International organizations such as the Organization for Economic Co-operation and Development (OECD) and the International Bank for Reconstruction and Development (World 


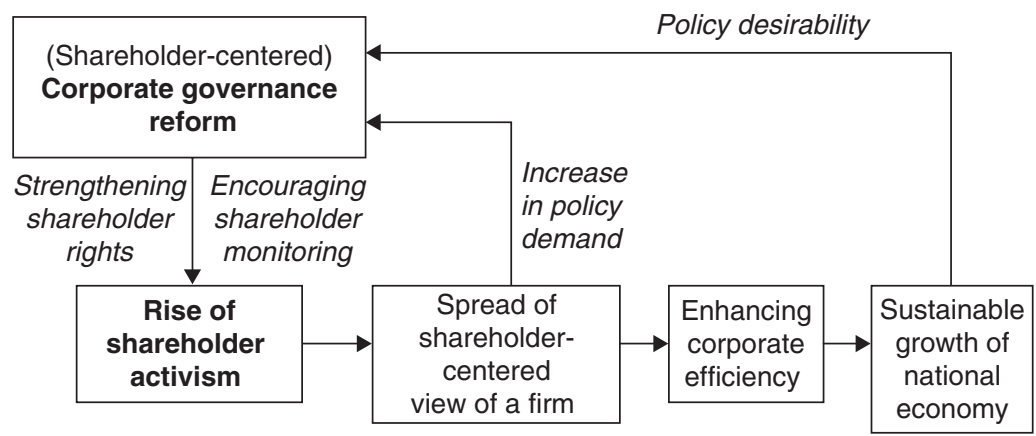

Figure 0.1 Shareholder activism in corporate governance reform

Bank) have helped developing and transition countries increasingly with the design and implementation of shareholder empowerment programs (World Bank, 1999). To take an example of a recent reform in an Asian developing country, the Malaysian government amended the Securities Commission Act in April 2000, allowing shareholders to pursue civil actions against companies, directors and their advisors ${ }^{3}$ (World Bank, 2000). Similarly in European transition economies, recent legal reforms have concentrated on investor protection and empowerment (Pistor, 2000).

\section{The growth of shareholder activism}

Apart from the causal relationship between policy change and the growth of shareholder activism, which will be discussed in Chapters 3, 5 and 8, shareholder activism has increased quite dramatically in recent years. To take an example from the US experience, the number of shareholder resolutions on corporate governance issues (excluding those proposed by individual shareholders) has increased more than seven-fold over the last two decades (Figure 0.2). Although there have been some fluctuations, the trend line in Figure 0.2 clearly shows a steady growth during the period.

Observers maintain that shareholder power is now spreading on a global scale. In January 1999, for example, Phillips and Drew Fund Management, Hermes Lens Asset Management and other large shareholders ousted David Montgomery from the position of chief executive of the UK media firm Mirror Group (Sherer, 1999). Since the early 1990s, Deutsche Schutzvereinigung für Westpapierbesitz (DSW), Deutsche Bank's mutualfund arm, has quietly prodded German companies to boost shareholder returns. The results of DSW's efforts were the restructuring of the three 


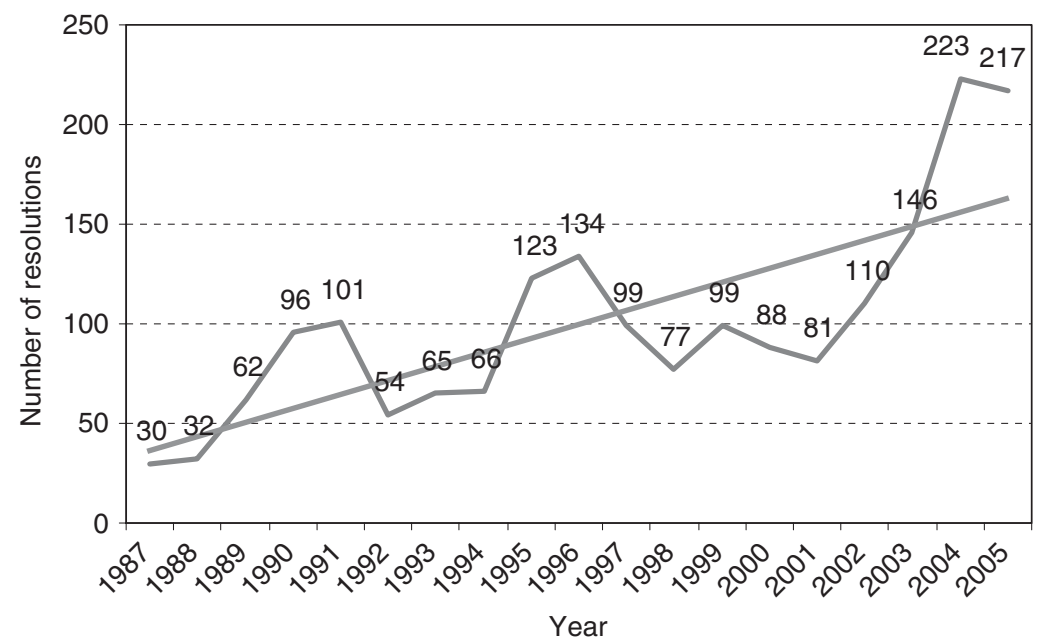

Figure 0.2 Growth of shareholder resolutions, US, 1987-2005

Sources: Gillan and Starks (2000), Georgeson Shareholder (various years). Annual Corporate Governance Review.

pillars of Germany Inc.: the conglomerate Siemens, the retailer Metro, and the chemical manufacturer Hoechst (Flynn, 1998). Shareholder activism can be observed in other corners of the world: to cite but a few, Hungary (Central European, 1999), Malaysia (Jayasankaran, 2000), China and Chile (Sherer, ibid.). Sherer (1999) concludes "[f]or years, agitating by stockholders was largely a US convention, held down overseas by long-held customs, practices or laws. ... Now the picture is starting to change (n.p.)".

\section{Studying the rise of shareholder activism}

Considering the relatively long history of activism by other stakeholders such as employees and consumers, shareholder activism is a relatively recent form. Nevertheless, the current rapid growth of shareholder activism has attracted considerable academic attention and consequently a large body of research has accumulated over the last two decades. Two early channels for publication were law and financial economics journals, but recent research outlets include journals of general management, business and society, and business ethics. Current articles on shareholder activism appear not only in journals specializing in corporate governance, but also in those in labor (Chakrabarti, 2004) and the environment (Monks, Miller and Cook, 2004). Much work has been done to understand the rise 
of shareholder activism (Gillan and Starks, 1998; Karpoff, 1998). Although some scholars have reviewed the literature in this area (Black, 1998; Gillan and Starks, 1998; Karpoff, 1998; Romano, 2001), there is still a need to understand this in a more systematic way.

Four chapters in Part I review the achievements in the area of shareholder activism and seek to analyze them in a more critical and comprehensive way. Chapter 1 questions what shareholder activism and its emergence mean and which aspect the study of shareholder activism has paid, and should pay, attention to. Using a general framework of decision-making, the following three chapters introduce three different approaches which previous scholars have taken, explicitly or implicitly, to explain the rise of shareholder activism. Each approach looks at a different stage, or aspect, of the emergence process and presents a different theoretical foundation. The first approach in Chapter 2 looks at the objective and observable existence of a problematic state so as to explain the occurrence of shareholder activism. Chapter 3 introduces the second approach, exploring the conditions under which a dissenting shareholder finally chooses activism among many various alternatives to correct an unsatisfactory situation. The third approach in Chapter 4 criticizes the rational unitary actor model of the previous two approaches, whether explicitly or not, and suggests a political and symbolic approach based on social movement theory to understand the rise of shareholder activism.

\section{The case of Korean shareholder activism}

The emergence of shareholder activism and related corporate governance reforms in Korea have been warmly commended by Western economists. For example, John Plender (2000), former chairman of Pensions and Investment Research Consultants Ltd (PIRC) and a lead writer of the Financial Times, once dubbed them the most impressive gain in Asian corporate governance reform. Other observers also cite the Korean case as an outstanding example of the global spread of shareholder power (e.g., Sherer, 1999; Wright, 1999). The leading activists are described as a "classic activist group" (Forbes, 2001) and as the creator of a shareholder rights movement (EIU, 2001). Thanks to this remarkable success, Jang Hasung, a leader of Korean shareholder activism, was chosen as one of 50 Asian Stars by Business Week in 1998 and 1999, and as one of Asia's best Advocates of Shareholder's Rights by Asia Week in 2000. Along with Adrian Cadbury and Ira Millstein, he was selected to receive one of the first International Corporate Governance Network (ICGN) Annual Awards in 2001. 
The prominent Korean shareholder activism was led by the People's Solidarity for Participatory Democracy (PSPD), a civil society organization. Originally it did not own shares of any target firms, nor was it concerned with enhancing shareholder rights. The PSPD's major concern is, as its name implies, participatory democracy, a political issue. Nevertheless, since its first shareholder activism against the Korea First Bank (KFB) in 1997, the PSPD has been leading Korean shareholder activism and has won international praise, as noted above. Despite its political nature, the PSPD is now piloting one of the most successful shareholder activism campaigns in developing countries.

What makes its success even more surprising is that the atmosphere in which the shareholder activism had emerged was not at first sight particularly favorable. Conventionally, Korea was thought to be a country where shareholders had been poorly protected, at least in practice, and almost inactive in corporate governance. It is a popular belief that, ever since the economy and the capital markets started developing in Korea since the 1960s, shareholder rights had usually existed only in legal textbooks and provisions. It has been believed that this poor corporate governance was one of the main causes of the 1997 financial crisis (e.g., IMF staff, 1998). Although the Korean government has continuously strengthened shareholder rights since 1998, even a survey of the public opinion on business reveals that most Koreans believe that business profits should be returned to the society rather than to the shareholders (Maeil Business News, 1999).

However, in December 1997, in the midst of the 1997 financial crisis, the PSPD launched its first shareholder activism; and its achievements since then have been highly praised. From this viewpoint, the PSPD exemplifies a unique case where an alternative activist group, a civil society organization, may complement or even encourage the monitoring role of more traditional activists such as institutional investors. Therefore, a question arising from the PSPD case is: "How could the shareholder activism led by the PSPD, a civil society organization, grow and thrive in the poor soil of Korea to become a success story of corporate governance reform in developing countries?"

The explosive development of shareholder activism in Korea might well become a matter of great concern for scholars (e.g., Kim and Kim, 2001; Choi and Cho, 2003; Milhaupt, 2004). Milhaupt (2004), for example, sees the dramatic rise of the PSPD and the series of remarkable victories achieved by PSPD-led shareholder activism as a real "puzzle". However, we have at least three challenges in applying the first and the second approaches reviewed in Part I to explain the PSPD case. First, an assumption 
that the PSPD tries to solve the problem of low stock returns through its shareholder activism is not plausible prima facie. Therefore, we need to examine what problems the PSPD is trying to solve and what meaning shareholder's financial interests, if any, bear in the PSPD shareholder activism. Second, we need to change the exit-voice alternatives that the existing theories of shareholder activism consider. If the PSPD, as a civil activist organization, tries to reform a current situation of a firm, it can regard neither exit nor takeover as appropriate alternatives. The alternative set of the PSPD as a civil society organization may contain traditional political voice options such as petitions, demonstrations, and boycotts. In this sense, it becomes important to examine how shareholder activism, an unusual voice tool, has entered into the PSPD's alternative set and why the PSPD has chosen it. Third, if the PSPD wants to take shareholder activism without having shares of the target firm, it will need to co-operate with shareholders of the firm to some extent. In this sense, we can apply the first or the second approaches to shareholder activism to the supportive shareholders rather than to the PSPD. However, this does not appear to be sufficient to explain the emergence of the PSPD activism fully.

For the reasons above, we think the third approach of social movement theory can address the three points above relatively well when we explore the rise of Korean shareholder activism. ${ }^{4}$ The three chapters in Part II investigate the three elements of social movement theory (political opportunity, framing process and resource mobilization) respectively. Chapter 5 investigates the political relations between the government, the PSPD and other civil activists. Chapter 6 addresses the process in which the activists view a situation, decide to use shareholder activism to change it and legitimize their action. Chapter 7 identifies what resources the Korean activists required and how they mobilized them successfully. Chapter 8 concludes with the findings and their implications for policymakers, scholars and corporate managers interested in corporate governance reforms, especially those achieved through shareholder activism. 